\title{
DAMPAK PERNIKAHAN DINI TERHADAP KEHARMONISAN KELUARGA DAN POLA ASUH ANAK (Studi Kasus Atas Masyarakat Desa Sukaraja Lampung Timur)
}

\author{
Oleh. \\ Heri Cahyono \& Eka Dewi \\ Universitas Muhammadiyah Metro \\ hericahyono808@gmail.com, ekadewi0012@gmail.com
}

\begin{abstract}
Early marriage affects the formation of a family that is not harmonious. That is because psychologically and socio-economically the early marriage partner is not yet mature. They are classified as unstable and generally do not have a permanent job. Besides being unstable, early marriage partners also do not have much knowledge about how to care for children, so they cannot apply the right pattern of parenting.

The hypothesis in this study is that there is the effect of early marriage on Family Harmony in the village of Sukaraja Tiga, Kec. Marga Tiga, Kab. East Lampung and there is an influence of early marriage on the pattern of child care in the village of Sukaraja Tiga, Kec. Marga Tiga, Kab. East Lampung. This study is a population study with a population of 15 early marriage partners. Data analysis in this study uses the Product Moment formula.

The results showed that the first hypothesis was accepted, as evidenced by the price of $r_{-}$xy 0.573 greater than $r_{-}$tabel at $\mathrm{df}=\mathrm{N}-\mathrm{nr}=15-2=13$ and a significance level of $5 \%$ at 0.514 , so it can be concluded that the theory that "marriage at the age young people will invite many unexpected problems because their psychological aspects are immature. It is not uncommon for couples who experience a collapse in a household due to a marriage that is too young "to be proven correct.

The second hypothesis is also accepted, as evidenced by the price of $\mathrm{r} \_x y$ 0.532 greater than $\mathrm{r} \_$tabel at $\mathrm{df}=\mathrm{N}-\mathrm{nr}=15-2=13$ and at the $5 \%$ significance level of 0.514 so it can be concluded the theory states that "Age is one of the characteristics of maturity where it can affect its role in children, because with increasing age a person occurs the process of maturity of both the organ and the way of his mind so that it can provide the right parenting for his child "proved correct.
\end{abstract}

Key word: Influence, Marriage, Harmony 


\begin{abstract}
Abstrak.
Pernikahan dini berdampak pada terbentuknya keluarga yang tidak harmonis. Hal itu karena secara psikologis dan sosial ekonomi pasangan pernikahan dini belum matang. Mereka tergolong masih labil dan umumnya belum memiliki pekerjaan tetap. Selain masih labil, pasangan pernikahan dini juga belum memiliki banyak pengetahuan tentang cara mengasuh anak, sehingga tidak dapat menerapkan pola pengasuhan anak yang tepat.

Hipotesis dalam penelitian ini adalah ada pengaruh pernikahan dini terhadap Keharmonisan Keluarga di desa Sukaraja Tiga, Kec. Marga Tiga, Kab. Lampung Timur dan ada pengaruh pernikahan dini terhadap Pola Pengasuhan Anak di desa Sukaraja Tiga, Kec. Marga Tiga, Kab. Lampung Timur. Penelitian ini merupakan penelitian populasi dengan jumlah populasi 15 pasangan pernikahan dini. Analisis data pada penelitian ini menggunakan rumus Product Moment.

Hasil penelitian menunjukkan bahwa hipotesis yang pertama diterima, terbukti dari harga $r_{x y} 0,573$ lebih besar dari $r_{\text {tabel }}$ pada $\mathrm{df}=\mathrm{N}-\mathrm{nr}=15-2=13$ dan taraf signifikansi 5\% sebesar 0,514, sehingga dapat disimpulkan bahwa teori yang menyatakan bahwa "perkawinan pada umur yang masih muda akan banyak mengundang masalah yang tidak diharapkan karena segi psikologisnya belum matang. Tidak jarang pasangan yang mengalami keruntuhan dalam rumah tangga karena perkawinan yang masih terlalu muda" terbukti benar.

Hipotesis yang kedua juga diterima, terbukti dari harga $r_{x y} 0,532$ lebih besar dari $r_{\text {tabel }}$ pada df $=\mathrm{N}-\mathrm{nr}=15-2=13$ dan pada taraf signifikansi $5 \%$ sebesar 0,514 sehingga dapat disimpulkan teori yang menyatakan bahwa "Umur menjadi salah satu ciri tingkat kedewasaan dimana dapat mempengaruhi perannya terhadap anak, karena dengan bertambahnya umur seseorang maka terjadi proses kematangan baik organ maupun jalan fikirannya sehingga dapat memberikan pola asuh yang tepat untuk anaknya" terbukti benar.
\end{abstract}

Kata kunci: Pengaruh, Pernikahan, Keharmonisan

\section{A. PENDAHULUAN}

\begin{tabular}{llcr}
\multicolumn{2}{c}{ Keharmonisan } & \multicolumn{2}{r}{ keluarga } \\
merupakan & harapan & dari & setiap \\
pasangan & suami & istri & yang \\
melangsungkan & \multicolumn{2}{c}{ pernikahan. }
\end{tabular}

Keharmonisan keluarga ialah keadaan tercapainya kebahagiaan dan kebersamaan setiap anggota dalam suatu keluarga dan sedikit sekali terjadi konflik, sehingga terbentuklah keluarga yang tenteram dan bahagia. ${ }^{1}$ Keluarga

\footnotetext{
${ }^{1}$ Asrizal, Kafa'ah Bingkai Keharmonisan Rumah Tangga, (Yogyakarta: Lembaga Ladang Kata, 2015), h. 51-52.
}

yang harmonis adalah keluarga yang rukun, bahagia, penuh cinta kasih serta jarang terjadi konflik dalam keluarga tersebut. Keluarga harmonis akan tercipta jika suami istri taat pada agama, menjalankan tugas dan tanggung jawab masing-masing, saling menghormati, saling menghargai, saling mencintai, saling pemaaf, saling bekerja sama, serta saling menjaga komunikasi.

Selain mengharapkan terciptanya keharmonisan keluarga, keberhasilan dalam mendidik atau mengasuh anak 
juga merupakan harapan dari setiap pasangan suami istri yang melangsungkan pernikahan. Hal itu karena kehadiran anak sangat dinantinanti oleh pasangan suami istri bahkan menjadi salah satu sumber kebahagiaan dalam rumah tangga.

Namun seiring dengan perkembangan zaman, tidak semua pasangan suami istri mampu menciptakan keharmonisan keluarga dan mampu mendidik anaknya dengan baik. Salah satu penyebabnya adalah kurang siapnya pasangan suami istri dalam menghadapi bahtera rumah tangga. Hal itu dipengaruhi oleh usia pasangan yang masih terlalu muda saat menikah.

Pernikahan dini merupakan ikatan lahir batin antara seorang pria dengan seorang wanita sebagai suami istri di usia yang masih muda/remaja".2 Menurut UU Nomor 1 Tahun 1974 Pasal 7 ayat (1), perkawinan hanya diizinkan jika pihak pria sudah mencapai umur 19 (sembilan belas) tahun dan pihak wanita sudah mencapai umur 16 (enam belas) tahun. ${ }^{3}$

Namun, Peraturan Pemerintah Republik Indonesia No 87 tahun 2014 pasal 24 ayat (1) bagian a, menjelaskan tentang pendewasaan usia perkawinan. Pendewasaan tersebut dalam rangka mensukseskan program Keluarga

\footnotetext{
${ }^{2}$ Namora Lumongga Lubis, Psikologi Kespro: Wanita dan Perkembangan Reproduksinya ditinjau dari Aspek Fisik dan Psikologinya, (Jakarta: Kencana Prenada Media Group, 2013), h. 80.

${ }^{3}$ Undang-Undang Nomor 1 tahun 1974 tentang Perkawinan Pasal 7 ayat 1.
}

Berencana. ${ }^{4}$ "Pendewasaan Usia Perkawinan (PUP) menurut BKKBN adalah upaya untuk meningkatkan usia pada perkawinan pertama, sehingga pada saat perkawinan mencapai usia minimal 20 tahun bagi perempuan dan 25 tahun bagi laki-laki". 5 Berdasarkan penjelasan tersebut dapat diketahui bahwa pernikahan dini merupakan pernikahan yang dilakukan oleh wanita berusia di bawah 20 tahun dan pria berusia di bawah 25 tahun.

Pernikahan dini berdampak pada terbentuknya keluarga yang tidak harmonis. Hal ini sesuai dengan teori yang menyatakan bahwa "Umumnya para pasangan muda keadaan psikologisnya masih belum matang, sehingga masih labil dalam menghadapi masalah yang timbul dalam perkawinan". ${ }^{6}$ Teori tersebut menunjukkan bahwa pasangan pernikahan dini masih labil dalam menghadapi masalah. Hal itu dapat menyebabkan permasalahan yang timbul dalam rumah tangga tidak terselesaikan dengan baik tetapi justru semakin rumit.

Perkawinan pada umur yang masih muda akan banyak mengundang masalah yang tidak diharapkan karena segi psikologisnya belum matang. Tidak jarang pasangan yang mengalami keruntuhan dalam rumah tangga karena

\footnotetext{
${ }^{4}$ Www.bpn.go.id/DesktopModules/Do cumentDownload.ashx.

${ }^{5}$ Indra Wirdhana, dkk, Pegangan Kader tentang Bimbingan dan Pembinaan Keluarga Remaja, (Jakarta Timur: Badan Kependudukan dan Keluarga Berencana Nasional, 2014), h. 13.

${ }^{6}$ Suryati Romauli dan Anna Vida Vindari, Kesehatan Reproduksi, (Yogyakarta: Nuha Medika, 2012), h. 112.
} 
perkawinan yang masih terlalu muda. ${ }^{7}$ Memang keharmonisan dalam keluarga tidak semata-mata dipatok oleh umur, karena semuanya dikembalikan kepada pribadi masing-masing. Tetapi umur biasanya mempengaruhi cara berpikir dan tindakan seseorang. Umur yang masih muda cenderung masih labil dalam menghadapi masalah serta menyebabkan seringnya terjadi konflik dan percekcokan yang berujung pada perceraian.

Selain itu, pasangan yang menikah muda juga belum matang secara sosial ekonomi. Umumnya mereka belum memiliki pekerjaan tetap sehingga kesulitan ekonomi pun memicu konflik dalam rumah tangga. Ketidakstabilan emosi serta kurangnya pengetahuan pasangan yang menikah muda terkait pola pengasuhan anak, juga menyebabkan mereka umumnya mendidik dan merawat anak-anaknya dengan pola asuh yang tidak baik.

Pernikahan dini masih terjadi di desa Sukaraja Tiga, Kecamatan Marga Tiga, Kabupaten Lampung Timur. Faktor penyebabnya adalah kondisi sosial ekonomi orangtua rendah sehingga anak dinikahkan meskipun masih berusia muda atau anak tidak melanjutkan pendidikan sehingga kemudian menikah muda. Hal tersebut untuk meringankan beban keluarga atau rendahnya ekonomi orangtua tersebut menyebabkan anak putus sekolah kemudian menikah muda. Selain itu, penyebabnya ialah telah lebih dahulu melakukan hubungan

${ }^{7}$ Bimo Walgito, Bimbingan dan Konseling Perkawinan, (Yogyakarta: Andi, 2004), h. 29. suami istri sehingga pernikahan dilangsungkan meskipun usia mereka masih tergolong sangat muda dan belum siap mengarungi bahtera rumah tangga. Kemudian, desa Sukaraja Tiga adalah desa yang mayoritas penduduknya bertani serta bekerja sebagai buruh. Apabila anak sudah dapat menggarap pertanian dengan baik atau sudah mampu bekerja sebagai buruh dianggap telah mampu menghidupi keluarga sehingga anak dinikahkan. $^{8}$

Berdasarkan hasil prasurvey yang penulis lakukan pada 05 Oktober 2016 terdapat 15 pasangan pernikahan dini di desa Sukaraja Tiga. Di antara 15 pasangan ini terdapat 3 pasangan yang telah bercerai dan banyak di antara mereka yang sering mengalami konflik atau percekcokan serta di antara mereka masih belum mampu mengasuh anak dengan baik.

Percekcokan atau perceraian tersebut dipicu oleh kondisi ekonomi keluarga yang rendah serta belum stabilnya emosi mereka. Kondisi ekonomi yang rendah tersebut disebabkan karena mereka belum memiliki pekerjaan tetap. Sedangkan belum stabilnya emosi disebabkan karena mereka masih tergolong muda, ego mereka masih tinggi sehingga sering memicu konflik.

Selain konflik yang berujung dengan perceraian tersebut, pasangan suami istri yang menikah muda juga belum dapat mengasuh anaknya dengan baik. Mereka sering menelantarkan, memarahi, membentak bahkan

${ }^{8}$ Wawancara dengan Warga desa Sukaraja Tiga pada 05 Oktober 2016. 
memperlakukan secara kasar seperti mencubit bahkan memukul anaknya ketika berperilaku yang tidak disukai oleh mereka atau sebaliknya mereka justru terlalu memanjakan anaknya. ${ }^{9}$ Berdasarkan kondisi di lapangan tersebut, penulis tertarik untuk melihat dampak pernikahan dini terhadap keharmonisan keluarga dan pola pengasuhan anak di Desa Sukaraja tiga kabupaten Lampung Timur.

\section{B. METODE PENELITIAN}

Jenis penelitian yang akan penulis lakukan termasuk kategori kuantitatif. Penelitian kuantitatif menekankan analisisnya pada data numerical (angka) yang diolah dengan metode statistika. ${ }^{10}$ Pada penelitian ini populasinya adalah semua pasangan pernikahan dini di dusun 6 , dusun 7 dan dusun 8 desa Sukaraja Tiga, Kecamatan Marga Tiga, Kabupaten Lampung Timur yang berjumlah 15 pasangan. Adapun teknik analisis data menggunakan rumus Korelasi PPM (Pearson Product Moment)

\section{KAJIAN TEORI}

Suatu pernikahan tentunya menginginkan rumah tangga yang harmonis. "Keharmonisan" berasal dari kata "harmonis" yaitu bersangkut paut dengan (mengenai) harmoni; seia sekata. "Keharmonisan" berarti keadaan harmonis, keselarasan dan

\footnotetext{
${ }^{9}$ Wawancara dengan beberapa tetangga pasangan pernikahan dini, pada 05 Oktober 2016.

${ }^{10}$ Edi Kusnadi, Metodologi Penelitian: Aplikasi Praktis, (Jakarta Timur: Ramayana Pers, 2008), h. 24-25.
}

keserasian". Sedangkan "Keluarga" adalah kelompok sosial terkecil yang umumnya terdiri atas ayah, ibu dan anak. ${ }^{12}$ Berdasarkan definisi tersebut, dapat diketahui bahwa keharmonisan keluarga adalah tercapainya keadaan harmonis atau serasi dalam suatu keluarga. Pendapat lain menjelaskan keluarga harmonis terbentuk berkat upaya semua anggota keluarga yang saling berinteraksi dan berkomunikasi dalam satu keluarga (rumah tangga). Dalam keluarga harmonis yang terbina bukannya tanpa problem atau tantangan-tantangan. Jika terjadi problem mereka selalu berusaha mencari penyelesaian dan menyelesaikan dengan cara-cara yang lebih familiar, menusiawi, dan demokratis. ${ }^{13}$ Keharmonisan keluarga merupakan keadaan tercapainya kebahagiaan dan kebersamaan setiap anggota dalam suatu keluarga dan sedikit sekali terjadi konflik, sehingga terbentuklah keluarga yang tenteram dan bahagia. ${ }^{14}$ Berdasarkan beberapa definisi tersebut, dapat diketahui bahwa keharmonisan keluarga adalah tercapainya suatu kebahagiaan, ketentraman, penuh kasih sayang, serta tercapainya komunikasi yang baik setiap anggota keluarga dan sedikit sekali terjadi konflik atau jika terjadi

\footnotetext{
${ }^{11}$ Departemen Pendidikan Nasional, Kamus Besar Bahasa Indonesia, (Jakarta: Gramedia Pustaka Utama, 2008), h. 484.

${ }^{12}$ Moh. Padil Triyo Supriyatno, Sosiologi Pendidikan, (Malang: UIN-Maliki Press, 2010), h. 116 .

${ }^{13}$ Mufidah, Psikologi Keluarga Islam: Berwawasan Gender, (Yogyakarta: UINMalang Press, 2008), h. 73.

${ }^{14}$ Asrizal, Kafa'ah Bingkai., h. 51-52.
} 
konflik, keluarga tersebut mampu menyelesaikan dengan baik.

Setidaknya ada enam aspek yang harus diperhatikan untuk menciptakan keluarga yang harmonis yaitu sebagai berikut: Kehidupan beragama dalam keluarga, mempunyai waktu untuk bersama, mempunyai pola komunikasi yang baik bagi sesama anggota keluarga (ayah-ibu-anak), saling menghargai satu dengan lainnya, masing-masing anggota keluarga merasa terikat dalam ikatan keluarga sebagai kelompok, bila terjadi suatu permasalahan dalam keluarga mampu menyelesaikan secara positif dan konstruktif. $^{15}$

Pola pengasuhan anak adalah cara-cara orangtua mengasuh anaknya untuk menolong dan membimbing supaya anak hidup mandiri. ${ }^{16}$ Pola pengasuhan merupakan faktor kontributif yang tidak dapat diabaikan. Terdapat 3 jenis pola asuh yaitu pola asuh otoriter, pola asuh permisif dan pola asuh demokratis. ${ }^{17}$ Pola asuh otoriter adalah pola asuh yang penekanan asuhannya pada kekuatan kontrol orangtua kepada anak dengan cara: (1) kepatuhan secara mutlak tanpa musyawarah; (2) anak harus menjalankan aturan secara mutlak tanpa alternatif lain; (3) bila anak berbuat salah, orangtua tidak segan menghukum; (4) hubungan anak dan orangtua sangat jauh; (5) lebih memenangkan orangtua bahwa orangtua yang paling benar; (6) lebih mengandalkan kekuatan orangtua, dengan memberi hadiah, ancaman dan sanksi; (7) kurang memerhatikan perasaan anak, yang penting perilaku anak berubah. ${ }^{18}$ Pola asuh permisif adalah pola asuh yang penekanan asuhannya serba membolehkan dengan penunjukan kasih sayang yang berlebihan serta disiplin rendah kepada anak. ${ }^{19}$ Pola asuh demokratis juga disebut sebagai pola asuh authoritatif. Pola asuh authoritatif adalah pola asuh yang menghargai anak secara pribadi dengan memberikan rasa tanggung jawab berdasarkan pada aturan. ${ }^{20}$

\section{PEMBAHASAN}

Ada pengaruh Pernikahan Dini terhadap Keharmonisan Keluarga di desa Sukaraja Tiga.

Setelah data pernikahan dini dan keharmonisan keluarga di desa Sukaraja Tiga, Kec. Marga Tiga, Kab. Lampung Timur berhasil dikumpulkan, maka selanjutnya dilakukan analisis terhadap data-data tersebut. Proses pengolahan dan analisa data yang penulis lakukan dalam penelitian ini adalah dengan menggunakan rumus Product Moment.

${ }^{15}$ Dadang Hawari, Al-Qur'an: Ilmu Kedokteran Jiwa dan Kesehatan Jiwa, (Jakarta: Dana Bhakti Prima Yasa, 1996), h. 215.

${ }^{16}$ Rahmat Rosyadi, Pendidikan Islam dalam Pembentukan Karakter Anak Usia Dini: Konsep dan Praktik PAUD Islami, (Jakarta: Rajawali Pers, 2013), h. 25.

${ }^{17}$ Ibid ., h. 26. 


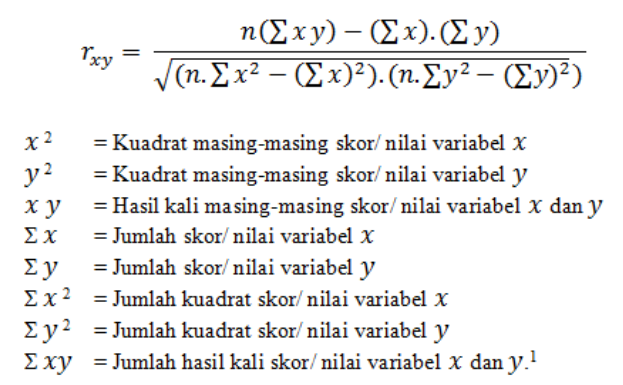

Setelah $r_{x y}$ diketahui, maka selanjutnya nilai $r_{x y}$ tersebut dikonsultasikan dengan $r_{\text {tabel }}$ Product Moment dengan kriteria $r_{x y}>r_{\text {tabel }}$ maka hipotesis alternatif diterima. Sebaliknya apabila $r_{x y}<r_{\text {tabel }}$ maka hipotesis ditolak. Berikut ini penulis sajikan tabel koefisien korelasi sebagai berikut:

\begin{tabular}{|c|c|c|c|c|c|}
\hline $\begin{array}{c}\text { No } \\
\text { Responden }\end{array}$ & $x$ & $y$ & $x^{\mathbf{2}}$ & $y^{\mathbf{2}}$ & $x \boldsymbol{y}$ \\
\hline 1 & 15 & 17 & 225 & 289 & 255 \\
\hline 2 & 20 & 19 & 400 & 361 & 380 \\
\hline 3 & 19 & 19 & 361 & 361 & 361 \\
\hline 4 & 22 & 24 & 484 & 576 & 528 \\
\hline 5 & 16 & 14 & 256 & 196 & 224 \\
\hline 6 & 20 & 19 & 400 & 361 & 380 \\
\hline 7 & 16 & 14 & 256 & 196 & 224 \\
\hline 8 & 17 & 18 & 289 & 324 & 306 \\
\hline 9 & 19 & 18 & 361 & 324 & 342 \\
\hline 10 & 16 & 17 & 256 & 289 & 272 \\
\hline 11 & 18 & 22 & 324 & 484 & 396 \\
\hline 12 & 20 & 20 & 400 & 400 & 400 \\
\hline 13 & 21 & 19 & 441 & 361 & 399 \\
\hline 14 & 18 & 23 & 324 & 529 & 414 \\
\hline 15 & 17 & 22 & 289 & 484 & 374 \\
\hline$\Sigma$ & $\mathbf{2 7 4}$ & $\mathbf{2 8 5}$ & $\mathbf{5 0 6 6}$ & $\mathbf{5 5 3 5}$ & $\mathbf{5 2 5 5}$ \\
\hline
\end{tabular}

Berdasarkan tabel di atas dapat diketahui sebagai berikut: $\mathrm{N}=15, \sum \mathrm{X}=$ $274, \sum \mathrm{Y} \quad=285, \sum \mathrm{X}^{2}=5066, \sum \mathrm{Y}^{2}=$ $5535, \sum X Y=5255$

$$
\begin{aligned}
& r_{x y}=\frac{n\left(\sum x y\right)-\left(\sum x\right) \cdot\left(\sum y\right)}{\left.\sqrt{\left(n \cdot \sum x^{2}-\left(\sum x\right)^{2}\right) \cdot\left(n \cdot \sum y^{2}-\left(\sum y\right)^{2}\right.}\right)} \\
& r_{x y}=\frac{15(5255)-(274) \cdot(285)}{\sqrt{\left(15.5066-(274)^{2}\right) \cdot\left(15 \cdot 5535-(285)^{2}\right)}} \\
& r_{x y}=\frac{78825-78090}{\sqrt{(75990-75076)(83025-81225)}} \\
& r_{x y}=\frac{735}{\sqrt{(914)(1800)}} \\
& r_{x y}=\frac{735}{\sqrt{1645200}} \\
& r_{x y}=\frac{735}{1282,65} \\
& r_{x y}=0,573
\end{aligned}
$$

Berdasarkan perhitungan di atas, diketahui bahwa nilai $r_{x y}$ sebesar 0,573 . Langkah selanjutnya adalah melakukan pengujian hipotesis dengan cara membandingkan besarnya harga $r_{x y}$ yaitu 0,573 dengan harga $r$ pada tabel. Untuk dapat membandingkan harga $r_{x y}$ dengan $r_{\text {tabel }}$, dicari derajat kebebasannya terlebih dahulu, yaitu df $=\mathrm{N}-\mathrm{nr}=15-2=13$. Pada df sebesar 13 diperoleh $r$ tabel dengan taraf kesalahan 5\% sebesar 0,514.

Berdasarkan hal tersebut dapat diketahui bahwa harga $r_{x y} 0,573$ lebih besar dari $r_{\text {tabel }} 0,514$ yakni $0,573>$ 0,514 , sehingga dapat diketahui bahwa hipotesis alternatif (Ha) dalam penelitian ini diterima, artinya Ada pengaruh Pernikahan Dini terhadap Keharmonisan Keluarga di desa Sukaraja Tiga, Kecamatan Marga Tiga, Kabupaten Lampung Timur.

Selanjutnya untuk mengetahui tingkat pengaruh variabel $\mathrm{X}$ terhadap variabel $\mathrm{Y}$, harga $r_{x y}$ dikonsultasikan dengan tabel interprestasi sebagai berikut: 


\begin{tabular}{|c|c|}
\hline Interval Koefisien & Tingkat Hubungan \\
\hline $0,80-1,000$ & Sangat Kuat \\
\hline $0,60-0,799$ & Kuat \\
\hline $0,40-0,599$ & Cukup Kuat \\
\hline $0,20-0,399$ & Rendah \\
\hline $0,00-0,199$ & Sangat Rendah \\
\hline
\end{tabular}

Berdasarkan tabel interpretasi di atas, diketahui bahwa nilai $r_{x y}$ sebesar 0,573 berada diantara nilai 0,40 sampai dengan 0,599, sehingga diketahui bahwa ada pengaruh yang cukup kuat antara variabel $\mathrm{x}$ (Pernikahan Dini) terhadap variabel y (Keharmonisan Keluarga) di desa Sukaraja Tiga, Kecamatan Marga Tiga, Kabupaten Lampung Timur..

Selanjutnya untuk mencari besarnya sumbangan (kontribusi) variabel $\mathrm{x}$ terhadap variabel $\mathrm{y}$, menggunakan rumus sebagai berikut: $\mathrm{KP}=\mathrm{r}^{2} \times 100 \%, \mathrm{KP}=0,573^{2} \times 100 \%$ $=32,83 \%$ Artinya Pernikahan dini memberikan kontribusi terhadap Keharmonisan Keluarga sebesar $32,83 \%$ dan sisanya $67,17 \%$ ditentukan oleh variabel lain.

Selanjutnya untuk mengetahui signifikansi pengaruh pernikahan dini terhadap keharmonisan keluarga dilakukan pengujian signifikansi koefisien korelasi dengan menggunakan rumus uji $t$ sebagai berikut:

Harga $\mathrm{t}$ hitung selanjutnya dibandingkan dengan harga t tabel.

$$
\begin{aligned}
& t \text { hitung }=\frac{r \sqrt{n-2}}{\sqrt{1-r^{2}}} \\
& t \text { hitung }=\frac{0,573 \sqrt{15-2}}{\sqrt{1-0,573^{2}}} \\
& t \text { hitung }=\frac{0,573 \sqrt{13}}{\sqrt{1-0,328}} \\
& t \text { hitung }=\frac{0,573.3,605}{\sqrt{0,672}} \\
& t \text { hitung }=\frac{2,066}{0,820} \\
& t \text { hitung }=2,519
\end{aligned}
$$

Harga $t$ hitung tersebut selanjutnya dibandingkan dengan harga t tabel. Adapun harga t tabel pada taraf signifikansi $5 \%$ dengan $\mathrm{df}=\mathrm{n}-2=15$ $2=13$ adalah 2, 160. Berdasarkan harga tersebut diketahui bahwa t hitung 2, 519 lebih besar dari t tabel. Hal ini berarti ada pengaruh yang signifikan pernikahan dini terhadap keharmonisan keluarga.

Ada pengaruh Pernikahan Dini terhadap Pola Pengasuhan Anak di desa Sukaraja Tiga.

Setelah data pernikahan dini dan pola pengasuhan anak di desa Sukaraja Tiga, Kec. Marga Tiga, Kab. Lampung Timur berhasil dikumpulkan, maka selanjutnya dilakukan analisis terhadap data-data tersebut. Proses pengolahan dan analisa data yang penulis lakukan dalam penelitian ini adalah dengan menggunakan rumus Product Moment.

$$
\begin{array}{ll} 
& r_{x y}=\frac{n\left(\sum x y\right)-\left(\sum x\right) \cdot\left(\sum y\right)}{\left.\sqrt{\left(n \cdot \sum x^{2}-\left(\sum x\right)^{2}\right) \cdot\left(n \cdot \sum y^{2}-\left(\sum y\right)^{2}\right.}\right)} \\
x^{2} & =\text { Kuadrat masing-masing skor/nilai variabel } x \\
y^{2} & =\text { Kuadrat masing-masing skor/nilai variabel } y \\
x y & =\text { Hasil kali masing-masing skor/ nilai variabel } x \text { dan } y \\
\Sigma x & =\text { Jumlah skor/nilai variabel } x \\
\Sigma y & =\text { Jumlah skor/nilai variabel } y \\
\Sigma x^{2} & =\text { Jumlah kuadrat skor/nilai variabel } x \\
\Sigma y^{2} & =\text { Jumlah kuadrat skor/nilai variabel } y \\
\Sigma x y & =\text { Jumlah hasil kali skor/nilai variabel } x \text { dan } y .{ }^{3}
\end{array}
$$


Setelah $r_{x y}$ diketahui, maka $=\mathrm{N}-\mathrm{nr}=15-2=13$. Pada df sebesar selanjutnya nilai $r_{x y}$ tersebut dikonsultasikan dengan $r_{\text {tabel }}$ Product Moment dengan kriteria $r_{x y}>r_{\text {tabel }}$ maka hipotesis alternatif diterima. Sebaliknya apabila $r_{x y}<r_{\text {tabel }}$ maka hipotesis ditolak. Berikut ini penulis sajikan tabel koefisien korelasi sebagai berikut:

\begin{tabular}{|c|c|c|c|c|c|}
\hline $\begin{array}{c}\text { No } \\
\text { Responden }\end{array}$ & $x$ & $y$ & $x^{\mathbf{2}}$ & $y^{\mathbf{2}}$ & $x y$ \\
\hline 1 & 15 & 20 & 225 & 400 & 300 \\
\hline 2 & 20 & 25 & 400 & 625 & 500 \\
\hline 3 & 19 & 27 & 361 & 729 & 513 \\
\hline 4 & 22 & 34 & 484 & 1156 & 748 \\
\hline 5 & 16 & 24 & 256 & 576 & 384 \\
\hline 6 & 20 & 29 & 400 & 841 & 580 \\
\hline 7 & 16 & 28 & 256 & 784 & 448 \\
\hline 8 & 17 & 21 & 289 & 441 & 357 \\
\hline 9 & 19 & 27 & 361 & 729 & 513 \\
\hline 10 & 16 & 20 & 256 & 400 & 320 \\
\hline 11 & 18 & 25 & 324 & 625 & 450 \\
\hline 12 & 20 & 19 & 400 & 361 & 380 \\
\hline 13 & 21 & 24 & 441 & 576 & 504 \\
\hline 14 & 18 & 21 & 324 & 441 & 378 \\
\hline 15 & 17 & 18 & 289 & 324 & 306 \\
\hline$\Sigma$ & 274 & 362 & 5066 & 9008 & 6681 \\
\hline
\end{tabular}

$r_{x y}=\frac{n\left(\sum x y\right)-\left(\sum x\right) \cdot\left(\sum y\right)}{\sqrt{\left(n \cdot \sum x^{2}-\left(\sum x\right)^{2}\right) \cdot\left(n \cdot \sum y^{2}-\left(\sum y\right)^{2}\right)}}$

$r_{x y}=\frac{15(6681)-(274) \cdot(362)}{\sqrt{\left(15.5066-(274)^{2}\right) \cdot\left(15.9008-(362)^{2}\right)}}$

$r_{x y}=\frac{100215-99188}{\sqrt{(75990-75076) \cdot(135120-131044)}}$

$r_{x y}=\frac{1027}{\sqrt{(914)(4076)}}$

$r_{x y}=\frac{1027}{\sqrt{3725464}}$

$r_{x y}=\frac{1027}{1930,15}$

$r_{x y}=0,532$

Berdasarkan perhitungan di atas, diketahui bahwa nilai $r_{x y}$ sebesar 0,532. Langkah selanjutnya adalah melakukan pengujian hipotesis dengan cara membandingkan besarnya harga $r_{x y}$ yaitu 0,532 dengan harga $r$ pada tabel. Untuk dapat membandingkan harga $r_{x y}$ dengan $r_{\text {tabel }}$, dicari derajat kebebasannya terlebih dahulu, yaitu df 13 diperoleh $r$ tabel dengan taraf kesalahan 5\% sebesar 0,514.

Berdasarkan hal tersebut dapat diketahui bahwa harga $r_{x y}$ 0,532 lebih besar dari $r_{\text {tabel }} 0,514$ yakni $0,532>$ 0,514, sehingga dapat diketahui bahwa hipotesis alternatif (Ha) dalam penelitian ini diterima, artinya Ada pengaruh Pernikahan Dini terhadap Pola Pengasuhan Anak di desa Sukaraja Tiga, Kecamatan Marga Tiga, Kabupaten Lampung Timur.

Selanjutnya untuk mengetahui tingkat pengaruh variabel $\mathrm{x}$ terhadap variabel $\mathrm{y}$, harga $r_{x y}$ dikonsultasikan dengan tabel interprestasi sebagai berikut:

\begin{tabular}{|c|c|}
\hline Interval Koefisien & Tingkat Hubungan \\
\hline $0,80-1,000$ & Sangat Kuat \\
\hline $0,60-0,799$ & Kuat \\
\hline $0,40-0,599$ & Cukup Kuat \\
\hline $0,20-0,399$ & Rendah \\
\hline $0,00-0,199$ & Sangat Rendah \\
\hline
\end{tabular}

Berdasarkan tabel interpretasi di atas, diketahui bahwa nilai $r_{x y}$ sebesar 0,532 berada diantara nilai 0,40 sampai dengan 0,599, sehingga diketahui bahwa ada pengaruh yang cukup kuat antara variabel $\mathrm{x}$ (Pernikahan Dini) terhadap variabel y (Pola Pengasuhan Anak) di desa Sukaraja Tiga, Kecamatan Marga Tiga, Kabupaten Lampung Timur.

Selanjutnya untuk mencari besarnya sumbangan (kontribusi) variabel $\mathrm{X}$ terhadap variabel $\mathrm{Y}$, menggunakan rumus sebagai berikut: $\mathrm{KP}=\mathrm{r}^{2} \times 100 \%, \mathrm{KP}=$ Nilai Koefisien 
diterima, $\mathrm{r}=$ Nilai Koefisien Korelasi. ${ }^{21}$ $\mathrm{KP}=0,532^{2} \times 100 \%=28,30 \%$

Artinya Pernikahan dini memberikan kontribusi terhadap Pola Pengasuhan Anak sebesar 28,30\% dan sisanya $71,70 \%$ ditentukan oleh variabel lain. Selanjutnya untuk mengetahui signifikansi pengaruh pernikahan dini terhadap pola pengasuhan anak dilakukan pengujian signifikansi koefisien korelasi dengan menggunakan rumus uji t, Harga $t$ hitung selanjutnya dibandingkan dengan harga t tabel.

$$
\begin{aligned}
& t \text { hitung }=\frac{r \sqrt{n-2}}{\sqrt{1-r^{2}}} \\
& t \text { hitung }=\frac{0,532 \sqrt{15-2}}{\sqrt{1-0,532^{2}}} \\
& t \text { hitung }=\frac{0,532 \sqrt{13}}{\sqrt{1-0,283}} \\
& t \text { hitung }=\frac{0,532 \cdot 3,605}{\sqrt{0,717}} \\
& t \text { hitung }=\frac{1,918}{0,847} \\
& t \text { hitung }=2,264
\end{aligned}
$$

Harga $t$ hitung tersebut selanjutnya dibandingkan dengan harga t tabel. Adapun harga t tabel pada taraf signifikansi $5 \%$ dengan $\mathrm{df}=\mathrm{n}-2=15$ $2=13$ adalah 2,160. Berdasarkan harga tersebut diketahui bahwa t hitung 2,264 lebih besar dari t tabel. Hal ini berarti ada pengaruh yang signifikan pernikahan dini terhadap pola pengasuhan anak.

\section{E. ANALISIS}

Keharmonisan keluarga adalah tercapainya suatu kebahagiaan, ketentraman, penuh kasih sayang, serta tercapainya komunikasi yang baik setiap anggota keluarga dan sedikit sekali terjadi konflik atau jika terjadi konflik, keluarga tersebut mampu menyelesaikan dengan baik.

Namun tidak semua pasangan suami istri mampu menciptakan keharmonisan keluarga. Salah satu penyebabnya adalah usia pasangan yang masih muda pada saat menikah. Hal ini sesuai dengan teori yang menyatakan bahwa perkawinan pada umur yang masih muda akan banyak mengundang masalah yang tidak diharapkan karena segi psikologisnya belum matang. Tidak jarang pasangan yang mengalami keruntuhan dalam rumah tangga karena perkawinan yang masih terlalu muda. ${ }^{22}$ Pernikahan dini merupakan faktor yang mempengaruhi terciptanya keluarga yang tidak harmonis. Selain itu, pasangan yang menikah muda juga belum matang secara sosial ekonomi. Umumnya mereka belum memiliki pekerjaan tetap sehingga kesulitan ekonomi pun memicu konflik dalam rumah tangga.

Sedangkan pola pengasuhan anak merupakan bentuk atau model upaya orangtua dalam menjaga, merawat, membimbing serta mendidik anaknya. Salah satu faktor yang berpengaruh pada pola pengasuhan anak adalah usia orangtua.

${ }^{22}$ Bimo Walgito, Bimbingan dan Konseling., h. 29. 
Umur menjadi salah satu ciri tingkat kedewasaan dimana dapat mempengaruhi perannya terhadap anak, karena dengan bertambahnya umur seseorang maka terjadi proses kematangan baik organ maupun jalan fikirannya sehingga dapat memberikan pola asuh yang tepat untuk anaknya. ${ }^{23}$

Teori tersebut menyatakan bahwa pernikahan dini mempengaruhi pola pengasuhan anak. Pasangan yang masih muda cenderung belum memiliki kedewasaan dalam mengasuh anak, mereka masih labil sehingga belum dapat mengasuh anaknya dengan baik.

Penelitian ini berupaya menjawab rumusan masalah yaitu sebagai berikut:

1. Apakah ada pengaruh pernikahan dini terhadap Keharmonisan Keluarga di desa Sukaraja Tiga, Kec. Marga Tiga, Kab. Lampung Timur?

2. Apakah ada pengaruh pernikahan dini terhadap Pola Pengasuhan Anak di desa Sukaraja Tiga, Kec. Marga Tiga, Kab. Lampung Timur?

Berdasarkan hasil pengujian hipotesis terkait rumusan masalah yang pertama menggunakan rumus Korelasi PPM (Pearson Product Moment) diperoleh harga $r_{x y} 0,573$ lebih besar dari $r_{\text {tabel }} 0,514$ yakni $0,573>0,514$, sehingga dapat diketahui bahwa hipotesis alternatif (Ha) dalam penelitian ini diterima. Artinya Ada pengaruh Pernikahan Dini terhadap Keharmonisan Keluarga di desa

${ }^{23}$ Lilis Maghfuroh, “ Hubungan Pola Asuh Orangtua dengan Prestasi Belajar Anak SDN 1 Kabalan Kecamatan Kanor Kabupaten Bojonegoro" dalam surya, Vol. 02, No. XVIII/ Juni 2014, h. 6-7.
Sukaraja Tiga, Kecamatan Marga Tiga, Kabupaten Lampung Timur, sehingga dapat disimpulkan bahwa teori yang menyatakan bahwa "perkawinan pada umur yang masih muda akan banyak mengundang masalah yang tidak diharapkan karena segi psikologisnya belum matang. Tidak jarang pasangan yang mengalami keruntuhan dalam rumah tangga karena perkawinan yang masih terlalu muda" terbukti benar.

Kemudian dari tabel interpretasi Koefisien Korelasi nilai $\mathrm{r}$ diketahui bahwa nilai $r_{x y}$ sebesar 0,573 berada diantara nilai 0,40 sampai dengan 0,599, sehingga diketahui bahwa pengaruh variabel x (Pernikahan Dini) terhadap variabel y (Keharmonisan Keluarga) di desa Sukaraja Tiga, Kecamatan Marga Tiga, Kabupaten Lampung Timur tergolong cukup kuat.

Berdasarkan perhitungan dengan menggunakan rumus $\mathrm{KP}=\mathrm{r}^{2} \times 100 \%$, diketahui bahwa kontribusi Pernikahan dini berpengaruh terhadap

Keharmonisan Keluarga sebesar $32,83 \%$. Kemudian berdasarkan pengujian signifikansi koefisien korelasi dengan menggunakan rumus uji $t$ diperoleh harga $t$ hitung sebesar 2,519 lebih besar dari t tabel 2,160 sehingga diketahui bahwa pernikahan dini berpengaruh signifikan terhadap keharmonisan keluarga.

Kemudian berdasarkan hasil pengujian hipotesis terkait rumusan masalah yang kedua menggunakan rumus Korelasi PPM (Pearson Product Moment) diperoleh harga $r_{x y} 0,532$ lebih besar dari $r_{\text {tabel }} 0,514$ yakni $0,532>0,514$, sehingga dapat diketahui bahwa hipotesis alternatif 
(Ha) dalam penelitian ini diterima, artinya ada pengaruh Pernikahan Dini terhadap Pola Pengasuhan Anak di desa Sukaraja Tiga, Kecamatan Marga Tiga, Kabupaten Lampung Timur, sehingga dapat disimpulkan teori yang menyatakan bahwa "Umur menjadi salah satu ciri tingkat kedewasaan dimana dapat mempengaruhi perannya terhadap anak, karena dengan bertambahnya umur seseorang maka terjadi proses kematangan baik organ maupun jalan fikirannya sehingga dapat memberikan pola asuh yang tepat untuk anaknya" terbukti benar.

Kemudian dari tabel interpretasi Koefisien Korelasi nilai $\mathrm{r}$ diketahui bahwa nilai $r_{x y}$ sebesar 0,532 berada diantara nilai 0,40 sampai dengan 0,599, sehingga diketahui bahwa pengaruh variabel x (Pernikahan Dini) terhadap variabel y (Pola Pengasuhan Anak) di desa Sukaraja Tiga, Kecamatan Marga Tiga, Kabupaten Lampung Timur tergolong cukup kuat.

Selanjutnya berdasarkan perhitungan dengan menggunakan rumus $\mathrm{KP}=\mathrm{r}^{2} \times 100 \%$, diketahui bahwa Pernikahan dini memberikan kontribusi terhadap Pola Pengasuhan Anak sebesar 28,30\%.

Kemudian berdasarkan pengujian signifikansi koefisien korelasi dengan menggunakan rumus uji $\mathrm{t}$ diperoleh harga $t$ hitung sebesar 2,264 lebih besar dari t tabel 2,160 sehingga diketahui bahwa pernikahan dini berpengaruh signifikan terhadap pola pengasuhan anak.

Berdasarkan penjelasan di atas, dapat disimpulkan bahwa Pernikahan Dini berpengaruh terhadap
Keharmonisan Keluarga di desa Sukaraja Tiga, Kecamatan Marga Tiga, Kabupaten Lampung Timur. Meskipun kontribusi pengaruhnya hanya $32,83 \%$, tetapi hal ini tidak boleh diabaikan karena pasangan yang menikah di usia dewasa, sudah matang secara mental dan finansial pun ada yang tidak mampu menciptakan keharmonisan keluarga, apalagi pasangan muda yang belum matang secara mental dan finansial, dan berdasarkan penelitian sudah terbukti menyebabkan ketidakharmonisan keluarga.

Selanjutnya, berdasarkan uraian sebelumnya, dapat disimpulkan pula bahwa Pernikahan Dini berpengaruh terhadap Pola Pengasuhan Anak di desa Sukaraja Tiga, Kecamatan Marga Tiga, Kabupaten Lampung Timur. Meskipun kontribusi pengaruhnya hanya $28,30 \%$, tetapi hal ini juga tidak boleh diabaikan karena penelitian ini sudah membuktikan bahwa Pernikahan Dini berpengaruh terhadap Pola Pengasuhan Anak, dan pengasuhan anak oleh orangtua adalah pengasuhan yang pertama dan utama bagi anak. Pengasuhan ini menjadi pondasi pembentukan akhlak dan perkembangan anak pada tahap selanjutnya. Sehingga, pengasuhan yang tidak baik akan membentuk akhlak yang tidak baik pula dan tidak maksimalnya kemampuan-kemampuan pada saat anak dewasa, sehingga hal ini penting untuk diperhatikan.

\section{F. KESIMPULAN}

Berdasarkan hasil penelitian yang telah penulis lakukan, dapat disimpulkan sebagai berikut: 
1. Ada pengaruh Pernikahan Dini terhadap Keharmonisan Keluarga di desa Sukaraja Tiga, Kecamatan Marga Tiga, Kabupaten Lampung Timur. Hal ini terbukti dari hasil pengujian hipotesis menggunakan rumus Korelasi PPM (Pearson Product Moment) diperoleh harga $r_{x y} 0,573$ lebih besar dari $r_{\text {tabel }}$ 0,514, sehingga dapat disimpulkan bahwa teori yang menyatakan bahwa "perkawinan pada umur yang masih muda akan banyak mengundang masalah yang tidak diharapkan karena segi psikologisnya belum matang. Tidak jarang pasangan yang mengalami keruntuhan dalam rumah tangga karena perkawinan yang masih terlalu muda" terbukti benar.

2. Ada pengaruh Pernikahan Dini terhadap Pola Pengasuhan Anak di desa Sukaraja Tiga, Kecamatan Marga Tiga, Kabupaten Lampung Timur. Hal ini terbukti dari hasil pengujian hipotesis menggunakan rumus Korelasi PPM (Pearson Product Moment) diperoleh harga $r_{x y} 0,532$ lebih besar dari $r_{\text {tabel }}$ 0,514 , sehingga dapat disimpulkan teori yang menyatakan bahwa "Umur menjadi salah satu ciri tingkat kedewasaan dimana dapat mempengaruhi perannya terhadap anak, karena dengan bertambahnya umur seseorang maka terjadi proses kematangan baik organ maupun jalan fikirannya sehingga dapat memberikan pola asuh yang tepat untuk anaknya" terbukti benar.

\section{G. REKOMENDASI}

Terbentuknya keluarga yang harmonis serta mampu mengasuh anak dengan baik merupakan hal-hal yang harus menjadi pertimbangan pasangan yang hendak melangsungkan pernikahan. Berkaitan dengan penelitian ini, dikemukakan saran-saran sebagai berikut:

1. Bagi pemuda dan pemudi yang hendak melangsungkan pernikahan, hendaknya mempertimbangkan beberapa hal seperti kesiapan fisik, mental, ilmu, baik ilmu agama maupun ilmu umum serta kesiapan ekonomi.

2. Bagi Orangtua agar senantiasa memperhatikan pendidikan anak, baik pendidikan agama, pendidikan formal dan pendidikan non formal agar adanya proses pendewasaan dan menikah pada usia yang seharusnya. Selain itu, bagi orangtua agar senantiasa memperhatikan pergaulan anak agar tidak terjadi pergaulan bebas yang dapat menyebabkan anak menikah muda.

\section{DAFTAR PUSTAKA}

Asrizal, Kafa'ah Bingkai Keharmonisan Rumah Tangga, Yogyakarta: Lembaga Ladang Kata, 2015

Bimo Walgito, Bimbingan dan Konseling Perkawinan, Yogyakarta: Andi, 2004

Dadang Hawari, Al-Qur'an: Ilmu Kedokteran Jiwa dan Kesehatan Jiwa, Jakarta: Dana Bhakti Prima Yasa, 1996 
Departemen Pendidikan Nasional, Kamus Besar Bahasa Indonesia, Jakarta: Gramedia Pustaka Utama, 2008

Edi Kusnadi, Metodologi Penelitian: Aplikasi Praktis, Jakarta Timur: Ramayana Pers, 2008

Indra Wirdhana, dkk, Pegangan Kader tentang Bimbingan dan Pembinaan Keluarga Remaja, (Jakarta Timur: Badan Kependudukan dan Keluarga Berencana Nasional, 2014

Lilis Maghfuroh, “ Hubungan Pola Asuh Orangtua dengan Prestasi Belajar Anak SDN 1 Kabalan Kecamatan Kanor Kabupaten Bojonegoro" dalam surya, Vol. 02, No. XVIII/ Juni 2014

Moh. Padil Triyo Supriyatno, Sosiologi Pendidikan, Malang: UIN-Maliki Press, 2010

Mufidah, Psikologi Keluarga Islam: Berwawasan Gender, Yogyakarta: UIN-Malang Press, 2008

Namora Lumongga Lubis, Psikologi Kespro: Wanita dan Perkembangan Reproduksinya ditinjau dari Aspek Fisik dan Psikologinya, Jakarta: Kencana Prenada Media Group, 2013

Rahmat Rosyadi, Pendidikan Islam dalam Pembentukan Karakter Anak Usia Dini: Konsep dan Praktik PAUD Islami, Jakarta: Rajawali Pers, 2013

Suryati Romauli dan Anna Vida Vindari, Kesehatan Reproduksi, Yogyakarta: Nuha Medika, 2012

Undang-Undang Nomor 1 tahun 1974 tentang Perkawinan Pasal 7 ayat 1.

Www.bpn.go.id/DesktopModules/Doc umentDownload.ashx. 